\title{
Informal governance in international organizations: Introduction to the special issue
}

\author{
Randall W. Stone
}

Published online: 2 April 2013

(C) Springer Science+Business Media New York 2013

International organizations have proliferated in recent decades. Virtually every issue of broad international concern is the subject of an international agreement that is administered by an international organization. Broad powers are delegated to some of these international agents, many of which exercise significant discretion and authority. International courts with broad jurisdiction and hundreds of more specialized judicial organs have been established to interpret a rapidly expanding body of international law. The organizational capacity of international governance has increased, while the capacity of domestic governance has declined in a range of failed states and contested territories. Meanwhile, the depth of policy coordination demanded by international agreements has led to an unprecedented level of international policy activism by some of the leading international organizations, including the IMF, the WTO, and the EU. Given the importance of what international organizations do, it is increasingly important to understand how international organizations actually work.

Most of our theoretical models of international organizations are based on their formal attributes rather than on their behavior. Formal rules are important, of course, and generally set the parameters within which informal interactions take place, but shared expectations and extra-legal practices often modify or overrule written provisions. As a result, models based on legal provisions can be misleading. For example, there are numerous international organizations in which votes are never taken, or are almost always unanimous; nevertheless, analyses of their governance often focus on the equilibria of majority voting games. Since the game being played does not involve building minimum winning coalitions, however, voting models based on majority voting can shed little light on the degree of influence that powerful countries exert over decision making, or on the practical limits of that influence. Similarly, procedural models of EU legislation assume that the game being played follows the legal procedures prescribed in the EU treaties; but this is often not the

R. W. Stone $(\triangle)$

Department of Political Science, University of Rochester, Rochester, NY 14627, USA

e-mail: randall.stone@rochester.edu 
case, because there are actions available that were not foreseen in the text. Consequently, models that treat the legal text as a description of the extensive-form game being played have little explanatory power (Thompson et al. 2006). Along similar lines, analysis based on the assumption that WTO rules governing reciprocity and most-favored-nation status are binding can be very misleading (Bagwell and Staiger 2002).

In each of these examples, the analysis is formalistic in the sense that it fails to take account of informal, or unwritten, behavioral regularities that modify the effect of the formal rules in potentially decisive ways. The effort to understand organizations only in terms of their formal rules is comparable to trying to understand computers only in terms of hardware, without reference to software, or trying to understand DNA only in terms of genes that code for proteins, without reference to the vast areas devoted to genetic switches that turn genes on and off.

In recent years, however, there has been a marked behavioral move in the study of international organizations, which parallels similar developments that occurred much earlier in other sub-fields of political science. The prerequisite for such a development was the creation of a critical mass of empirical research on a variety of international organizations. As in other sub-disciplines, the way was led by studies of formal institutional details: the legalization of international relations (Goldstein et al. 2000), the formal design elements of international organizations (Koremenos et al. 2001), and formal delegation to international agents (Hawkins et al. 2006). Beginning about the same time, a surge of quantitative empirical work arose that focused on particular international organizations. A flood of research emerged on the politics of the IMF (Stone 2002, 2004, 2008; Vreeland 2003; Gould 2006; Dreher and Vaubel 2004; Dreher and Jensen 2007; Chwieroth 2010; Pop-Eleches 2009; Copelovitch 2010; Steinwand and Stone 2008) and the world bank (Dreher et al. 2009; Fleck and Kilby 2006). Meanwhile, an even larger literature was growing that studied all aspects of policy making in the European Union with an increasing degree of empirical and theoretical sophistication (König et al. 2006; Schneider 2009; Thompson et al. 2006). Simultaneously, a sophisticated empirical literature has emerged that studies dispute resolution in the WTO, the emergence of preferential trade agreements and the proliferation of bilateral investment treaties (Reinhardt 2001; Steinberg 2002; Davis 2003, 2004, 2012; Busch and Reinhardt 2003; Mansfield and Reinhardt 2003; Büthe and Milner 2008; Mansfield and Milner 2012). Along the way, a number of anomalies have emerged that challenge the paradigm of explaining outcomes in terms of formal-legal treaty provisions, and scholars working in diverse areas have converged on an appreciation of the significance of informal governance in international organizations. This was the motivation behind devoting a special issue of this journal to the subject.

In response to the call for papers, the journal received a large number of empirically rich studies of informal governance in a wide range of international organizations, and only a few could ultimately be published. The submissions highlighted the role of informality in the international trade and investment regimes; in international security; in the UN General Assembly and in UN functional organizations; in international financial institutions, multilateral development banks, in the Bank for International Settlements; and in regional organizations (EU, NAFTA, Mercosur, ECOWAS, CARICOM, ASEAN, CIS). In all of these varied contexts, the authors argued that it was impossible to understand how international governance works 
simply by focusing on legal texts and formal rules. Informal governance provides the operating system that renders the behavior of international organizations coherent.

The field is in an early stage of theorizing about informal governance in IOs, and this is reflected in the fact that the term has been given multiple meanings by a variety of authors. The phenomena under discussion here have a common denominator, however. Our common definition of informal governance is the systematic influence of unwritten rules, shared expectations or norms within international organizations that substantially modify or substitute for formal treaty provisions. Informal governance prevails when informal influence overrides legal procedures, or when important rules are unwritten. The authors included in this issue disagree about why informal governance arises, however, and a degree of theoretical heterogeneity among the contributions is desirable because the purpose of the issue is to open up questions rather than to attempt to force a premature resolution. In particular, the authors disagree about the weight they place on conflict of interest and the distribution of power in their explanations, as opposed to functionalist imperatives that lead everyone to adopt Pareto-improving alternatives. In what follows, I propose a theoretical framework in which states are the primary actors, and states design institutions to allow for a degree of informality that balances the participation constraints of powerful and weak states. The individual contributions react to this framework, in some cases drawing on it heavily, and in others modifying or contesting it in important ways.

\section{Functionalist vs. power-based explanations}

Functionalism is an approach that explains causes in terms of their anticipated effects. We have traffic lights because they reduce traffic accidents; we have international organizations because there exist important common interests in international cooperation that can be realized only through coordinated action. This is a theoretical move that is broadly consistent with the rational choice approach to political science, with its emphasis on interdependent, strategic decision making by actors that anticipate the consequences of their choices. However, functionalism tends to abstract away from the agents. Someone has to put up the traffic lights and decide which traffic flows deserve priority, and someone has to design the international institutions. In international relations, furthermore, functionalism has generally been combined with the transaction-cost approach to explaining organizational design. Transaction costs are the costs of making deals: identifying partners, bargaining over settlements, and enforcing agreements (Coase 1960). Institutions that reduce transaction costs can be generally beneficial because they facilitate efficient exchange, and this provides a possible motivation for organization design (Williamson 1975, 1985). However, the transaction-cost approach tends to abstract away from conflicting interests. Lowering barriers to trade creates winners and losers, and even equally efficient arrangements can have greatly differing distributional consequences.

The scholar who did the most to popularize functionalism and the transaction-cost approach in international relations, Robert O. Keohane, also took pains to point out their characteristic blind spots. Keohane (1984) argued that international institutions are created in order to facilitate cooperation by reducing transaction costs, but he 
argued that they were created by the most powerful states for their own purposes, and were generally skewed to favor their interests. He thought it was naïve to expect institutions to be efficient, and regarded as an empirical question whether they were Pareto-improving outside the circle of voluntary participants. OPEC stood for him as a powerful counterexample. When he sought to explain institutional design, the most important variables were issue-specific power, the institutional status quo, and technology (Keohane and Nye 1977).

In contrast, much of the recent work that was inspired by Keohane's research has sought to explain institutional design in terms of functional imperatives to reduce transaction costs. The trend towards increased legalization of international cooperation was explained as a consequence of the transactional benefits of clarifying expectations: formal law and the judicial apparatus that interprets and applies it allow for convergence of expectations, streamline bargaining and facilitate monitoring and enforcement (Goldstein et al. 2000). In particular, Abbott and Snidal (2000) argued that the choice between hard (legally binding and enforceable) and soft law (nonbinding or non-enforceable) was based on a trade-off between the benefits of precise obligations for enforcement and the benefits of flexibility to accommodate unforeseen circumstances. Similarly, the rational design project (Koremenos et al. 2001) explained the design of international organizations - their degree of centralization, scope of activity and membership - in terms of the transaction costs and market failures that they were created to address. Along similar lines, delegation of discretionary powers to international organizations has been cast in terms of optimal tradeoffs between the costs of opportunism (decentralized markets) and the costs of agency (centralized hierarchies) (Hawkins et al. 2006.) None of this work offers much scope for the hypotheses that countries might disagree about the optimal design of institutions, or that institutional design might reflect the distribution of power among them. Several of these authors are represented in the current issue, however, and while they continue to emphasize the importance of transaction costs, they have also incorporated a serious consideration of power and conflict of interest.

\section{Informal governance: A theoretical framework}

The theoretical framework proposed here puts the distribution of power and interests at the center of the study of international organizations. ${ }^{1}$ Formal institutions play an essential role in international relations, but all international organizations operate to some degree at variance with their formal rules. The formal rules - standard operating procedures, voting rules, organizational chains of command, written policies - provide stable and predictable policy outputs. Derogations from these standard procedures are made to safeguard the interests of powerful states.

The model of informal governance defines three distinct kinds of power. Structural power is the availability of attractive outside options which impose negative externalities on other states. These options need not be exercised in order to influence the

\footnotetext{
${ }^{1}$ The discussion in this section is based on Stone (2011). The book lays out the argument in considerably more detail, formalizes it in a game-theoretic model, and presents case studies and statistical tests of hypotheses.
} 
course of events; they represent potent off-the-equilibrium-path strategies that condition the way the game is played. Indeed, the key to effectively exploiting structural power is to avoid being compelled to use it overtly. Formal power consists of voting rights, veto power, membership on committees, or other control rights that are legally assigned to members of an organization. The distribution of formal power determines the organization's policy outputs in ordinary times. Informal power consists of the ability to obtain desirable outcomes within an organization, at some cost, by going outside of normal channels. For example, it might consist of lobbying an international executive or influencing the agenda. Powerful countries have advantages over weaker states in exerting informal power, including superior information, immediate access to key personnel, and greater cooperation with their requests. In addition, they can generally rely on deference from other states, which prefer to avoid confrontations when their own key interests are not engaged. As some of the contributions to this issue emphasize, however, informal influence is not necessarily monopolized by leading states.

The interests of powerful states must be accommodated when they are intense, because powerful states have credibility problems that weaker states do not share. Countries that have attractive outside options cannot credibly commit to following rules that would severely impair their interests, while weaker states can credibly commit because they find reneging less attractive. This suggests the possibility of an inter-temporal exchange: powerful states are granted temporary control of organizational policy when their interests are strongly affected, and in return weaker states are granted a share of formal control rights during ordinary times that is out of proportion to their capabilities.

There is rarely an explicit social contract. Informal influence does not have to be explicitly provided for in organizational design, because powerful countries can always find ways to stack the deck if they are not prevented. However, the design of standard procedures and governance mechanisms can be structured to make informal manipulation more or less costly. For example, the IMF's non-transparent decision making procedures and weak Executive Board facilitate the exercise of informal influence. ${ }^{2}$ The most important design feature is delegation, which may take the form of executive, legislative or judicial powers. Delegating judicial powers insulates decision making from informal influence to a substantial degree, because judgments have to be justified according to legal reasoning, and it is putatively illegitimate for a party to seek to manipulate the process. The WTO dispute resolution procedure is an example of this kind of legalized cooperation. ${ }^{3}$ On the other hand, exercising informal influence is less costly when IOs are granted executive discretion, so it should be expected to be more prevalent. Legislative delegation is an intermediate solution, because deliberations are transparent and the actors are states rather than agents, but informal influence can be exercised at the stage of agenda setting.

In this view, the design features of international organizations are equilibrium outcomes of a game that balances the power and interests of the leading state, or group of states, and the rest. Informal meddling by great powers is made costly

\footnotetext{
${ }^{2}$ IMF governance has been reformed to some degree in recent years and has made great strides in making lending conditions more transparent to the wider public, but this has not affected the weakness of the Executive Board or the non-transparency of decision making vis-à-vis the membership.

${ }^{3}$ WTO dispute resolution is not legally binding, but follows a transparent, legal procedure based on case law and precedent.
} 
enough, usually in terms of bad publicity, to keep manipulation from becoming routine. The cost cannot be excessive, however, or the leading power might disengage from the organization, which would lower the value of cooperation for other participants. In this sense, the rank-and-file members of the organization acquiesce in the governance mechanisms that allow powerful states to exert informal influence in order to assure that powerful states will participate. What weak states will accept, however, depends upon their own participation constraints. Membership in an international organization must be attractive enough in expectation, taking its formal and its informal features as a package, to be superior to exit. This puts an upper bound on the degree of opportunism that powerful states can display, and it requires that informal prerogatives of the powerful are compensated with a degree of formal control by the weak. In this sense, the legitimacy of the organization is a binding constraint that influences institutional design.

The more skewed the distribution of power and the more volatile the leading power's interests in a particular issue area, the more informality we should see. In the European Union, for example, governance is more informal in security policy than in trade. On the other hand, as power becomes more diffused and additional countries gain the ability to manipulate the agenda, high levels of cooperation become unattainable without transforming governance to make it more transparent, legalized and accountable. The EU illustrates this point as well, because it was stuck at a low level of integration for many years until common interests became so overriding that the leading states became willing to accept the formalization embodied in the Single European Act of 1986 and the Maastricht Treaty of 1991.

\section{Articles in the special issue}

The articles in this special issue focus on a range of organizations and issues, but they divide neatly into two broad themes: institutional design and organizational behavior. The first four papers deal with puzzles regarding institutional design. Vabulus and Snidal ask why some organizations are entirely informal. Marcoux and Urpelainen ask why states incorporate enforcement provisions in treaties, but then fail to use them; Koremenos, on the other hand, asks why treaties that we would expect to have enforcement provisions have none, although enforcement appears to take place nevertheless. Obydenkova and Libman investigate the Commonwealth of Independent States (CIS), an organization consisting primarily of non-democratic countries, and ask why members choose to participate in some agreements, but not in others. Each of these questions focuses on formal aspects of institutional design: the existence or absence of formal provisions, and the decision to formally join a treaty or not. However, the politics behind the decisions is thoroughly informal. For Obydenkova and Libman, the decision to sign a treaty in the CIS is a calculation about how far to appease Russia without becoming too deeply ensnared, and depends upon the attractiveness of the signatory state's outside options. Koremenos finds that enforcement provisions are often left out because powerful states prefer to leave them unwritten, relying instead on informal procedures. Marcoux and Urpelainen argue that many written provisions are never intended to be used, and that influential states only agree to them because enforcement is not credible. 
The following papers focus on how informal governance takes place in international organizations. Chwieroth studies the IMF, and argues that informal governance takes place both at the level of interactions among the member states and at the level of the staff. Kleine investigates legislative politics within the EU, and argues that the legislative process departs markedly from the voting system set down in the EU treaties. Morrison investigates the pattern of World Bank lending, and finds that favoritism towards developing countries that were members of the Executive Board has declined as a result of institutional reforms. He argues that the reforms came about because of an astute use of informal influence by the United States and other leading donors.

Taken as a whole, the articles broadly support the argument laid out above, but with important nuances that indicate that a lively discussion is likely to prevail for years to come. Consensus reigns on the substantive importance of informal governance defined as systematic departures from written rules and official governance mechanisms, and this is striking because of the wide range of organizations and issue areas surveyed. There is less agreement on underlying causes. Most of the authors find evidence to support the claim that informal governance serves the interests of powerful countries, although they differ in the weight that this plays in their explanations. For most, including Morrison, Koremenos, Marcoux and Urpelainen, and Obydenkova and Libman, power plays the primary role in determining patterns of informal governance. For Chwieroth and for Vabulus and Snidal, state power plays an important supporting role, but there are other critical reasons for informal governance as well. Kleine disputes the importance of state power in her case. Three of the papers argue for an important role for functionalist explanations. Kleine takes the strongest position in favor of functionalism, arguing that the development of informal governance in European legislation was driven by the need to accommodate the domestic political interests of governments while deterring unjustified special pleading. Vabulus and Snidal entertain a range of explanations for the emergence of informal international organizations, prominently including the interest in mitigating transaction costs, but argue that the creation of informal organizations is often contested by states that are excluded. Koremenos gives pride of place to transaction costs in explaining the inclusion of formal enforcement provisions in international treaties, but argues that power plays an important role in explaining the anomalous treaties that do not include such provisions, although the rational design approach predicts that they should.

\subsection{Institutional design}

Vabulus and Snidal conduct a survey of informal international organizations - organizations that have no secretariats and are not established by a formal treaty-and seek to explain why countries choose this form of organization rather than creating formal intergovernmental organizations. Their argument rests mainly on functional logic: countries choose informal rather than formal intergovernmental organizations when they value rapid decision making and confidentiality more than efficient implementation and consistency. There is a trade-off between different kinds of transaction costs that can prevent effective cooperation, and different organizational 
forms are superior for different problems. However, they also make several important arguments about the role of power in informal organizations. First, they note that informal organizations may be important power resources for powerful states. As I argued in Controlling Institutions (2011), the various G-groupings, and particularly the G-7, have served U.S. foreign policy well as confidential settings that have allowed the United States to steer decision making in more inclusive institutions such as the IMF. Most major policy innovations at the Fund were announced in the G7 first, and in this sense the two institutions were nested. The eclipse of the G-7 and the rise of the G-20 in recent years, in this sense, represented a change in the informal governance of the IMF. ${ }^{4}$ Vabulus and Snidal argue, however, that many informal groupings consist of weak states and are intended to bolster their collective bargaining power-for example, various groups of states have formed within the trade regime to press their particular agendas. In addition, they argue that informal organizations may more quickly reflect shifts in the balance of power than do the formal rules of international organizations, and in this way they promote flexibility that may help to preserve formal intergovernmental organizations in the face of fluctuating pressures.

Koremenos focuses on another dimension of institutional design, the inclusion of formal enforcement measures in international treaties, and asks why enforcement provisions are left out. Her key insight in this paper is that the absence of formal enforcement measures does not necessarily imply the absence of enforcement, which can also be provided through informal governance. Relying on the logic developed in her previous project on rational design, she argues that the nature of transaction costs in particular issue areas (the type of cooperation problem faced, the nature of commitment problems, and the difficulty of monitoring policies) determines the demand for formal enforcement mechanisms. The model does not perfectly predict the assignment of formal enforcement mechanisms, but she argues that when formal enforcement measures are absent in difficult issue areas where enforcement is valuable, enforcement is likely to be provided informally. The empirical strategy relies on a rich data set that is constructed on a sample that is randomly drawn from the population of international treaties. The first stage of her analysis uses covariates that capture transaction costs and cooperation problems to predict formal enforcement mechanisms, and the second stage uses measures of regime heterogeneity and the distribution of power to explain anomalous false positive cases, which were predicted to include formal enforcement mechanisms but do not. She goes on to investigate several cases in detail, and finds that enforcement is indeed provided informallysometimes because treaties are implicitly nested in other organizations, and sometimes by great powers acting unilaterally. She concludes that informal governance helps to explain some of the missing formal institutional details.

Marcoux and Urpelainen analyze the flip side of Koremenos' empirical question: they ask why countries negotiate treaties that include formal enforcement provisions, but then choose not to use those provisions when signatories fail to comply. In their

\footnotetext{
${ }^{4}$ In this sense, the G-8 never really supplanted the G-7, because Russia was not included in the most delicate financial deliberations. Indeed, even after the rise of the G-20, important IMF lending decisions have still been preceded by conference calls involving the G-7 deputy finance ministers, so some essential informal functions have not changed.
} 
argument, informal governance substitutes for flexible formal provisions. They model a stylized situation in which one group of countries, the North, negotiates for environmental reforms that are costly to implement for another group of countries, the South. Domestic actors or NGOs apply pressure for treaties with impressive formal enforcement provisions, and in some cases governments negotiate such treaties in order to deflect criticism, without necessarily intending to bear the costs of eventual enforcement. The environmental rider to NAFTA that the Clinton administration negotiated in order to secure Congressional ratification is a case in point. In some cases, indeed, the target countries agree to such provisions only if they are reasonably confident that they will never actually be applied. Informal influence allows countries to reach agreement in spite of domestic pressures that might otherwise shrink the zone of agreement to the vanishing point. The more powerful the countries of the South, or the more attractive their outside options, the more confident they can be that formal sanctions will not be applied, and therefore the more willing they are to incorporate them into the text. The bilateral balance of power between environmental leaders and environmental laggards determines the informal governance of the regime, which in turn shapes the laggards' participation constraint - the legitimacy of the treaty regime. Marcoux and Urpelainen analyze data on international environmental treaties and find evidence consistent with this conclusion. Taken together, the Koremenos and Marcoux-and-Urpelainen papers suggest that formal enforcement provisions may be only weakly associated with actual enforcement, since informal enforcement occurs in cases where treaties do not provide for it, and enforcement provisions are sometimes included in treaties only because informal politics assures that invoking them is not credible.

Obydenkova and Libman analyze the case of the Commonwealth of Independent States, which they characterize as one of a small number of international organizations with a majority of non-democratic members. The CIS, which replaced the Soviet Union, has become one of the most active regional integration organizations in terms of treaty production, but it remains an organization with relatively shallow substantive cooperation outside of the core states of Russia, Belarus and Kazakhstan. The authors argue that most of this legal productivity is symbolic, and that Russia uses CIS treaties primarily as means to rally its neighbors around its diplomatic initiatives, but that legal entanglement comes with the danger that Russia will be able to increase its informal influence. Russia's neighbors, in turn, weigh the costs of offending Russia against the dangers of entrapment when they choose whether to participate. The result is that the most democratic CIS members are least willing to participate by signing additional treaties, because their ideal points are furthest from that of Moscow. Controlling for democracy, however, the countries with the most advanced market reforms and those with the most energy independence - in short, the countries with the best exit options - are the most willing to propitiate Russia by signing CIS agreements. Obydenkova and Libman find that the legitimacy of the regime - the weaker state's participation constraint - is a function of its balance of power with the leading state and the effects that has on the informal functioning of the regime.

\subsection{Organizational behavior}

Chwieroth investigates the informal politics of access to IMF resources and finds a systematic pattern of favoritism for U.S. allies, but he focuses on a more insidious 
form of patronage in IMF lending that favors countries with top economic decision makers who were educated in Anglo-American economics departments. He argues that the size of a loan offered to a country is subject to a series of subjective judgments that are made by the Staff and ultimately ratified by the members of the Executive Board. In this process, the Staff plays a key agenda-setting role, and the Staff naturally favors countries that are represented by officials that share its own training in economics. He attributes this pattern both to normative views held by the IMF Staff and to their pragmatic career incentives to promote lending that is likely to be successful. Indeed, quantitative tests indicate that countries that are represented by economists receive substantially larger loans from the Fund, and that this effect has increased as the Fund's own staff has become more strongly dominated by economists. The study also finds that countries that enjoy close political relations with the United States receive larger loans, which supports the interpretation that the United States exerts informal influence to obtain larger IMF loans for its allies and countries with strong economic ties (Thacker 1999; Oatley and Yackee 2004). The effects of state-driven informal influence and Staff-led agenda setting appear to operate simultaneously, although the current research design does not make it possible to determine whether they operate in the same countries. It would be consistent with this evidence, for example, if Staff influence operated in smaller countries and in normal times, while U.S. influence was exerted only in particularly important cases where strong U.S. interests are engaged. The paper convincingly shows that the size of IMF loans is strongly influenced by informal governance, that this influence has multiple sources, and that the preferences of the Staff can be decisive.

Kleine investigates European legislation, which involves action by the European Commission, the Council and the European Parliament. The article and a forthcoming book (Kleine 2013) argue that the nature of the game being played has little to do with the formal procedures prescribed by EU treaties because the sequence of actions is malleable and legislation is embedded in an on-going process of negotiation. An important objective of the participants in these negotiations is to avoid pushing any of the governments too far; instead, they practice a kind of diffuse reciprocity that protects each other's fragile domestic coalitions when issues take on political significance. As a result, governments that are outliers in terms of their policy preferences tend to have disproportionate influence, but this creates an incentive problem: governments can exploit the norm by pleading for special treatment even when their vital interests are not engaged. The problem, then, is how to separate the honest protests from the dishonest ones, and Kleine argues that this function has been taken on by the rotating Council presidency. When the government holding the presidency is perceived to have no interest in deferring to the preferences of a state that pleads a strong interest in the issue, it is able to credibly broker a compromise; when it has an interest in carving out exceptions for itself, however, it cannot act credibly and therefore defers the issue to the next semi-annual presidency. ${ }^{5}$ Kleine argues that diffuse reciprocity is optimal from the point of view of all governments because it prevents European legislation from stretching too far the social fabric of consent on

\footnotetext{
${ }^{5}$ The argument is consistent with modeling IO influence as a cheap-talk signaling game, as in Fang and Stone (2012).
} 
which European integration is based, and she attributes much of the resilience of the integration project to this informal practice.

Kleine does not find a tension between informality and legitimacy in her case, and indeed, she detects no evidence that deference depends upon the distribution of material resources. This is a striking contrast with the model of informal governance. One possible interpretation is that Kleine's functionalist informality and the powerbased model relate to different parts of a common parameter space. Kleine's cases are routine legislative problems with relatively low stakes for the majority of the participants, and there the role of power seems to be muted, but the conclusions might be different if she investigated the high politics of bailouts in the Eurozone. Recent events suggest that informal bargaining and resource asymmetries become very important in European decision making when critical German interests are affected. In these cases, all of the participants have existential interests at stake, and the resulting conflicts have profound implications for the legitimacy of the Union.

Morrison investigates the distribution of grants distributed by the International Development Agency of the World Bank and focuses on competition between two forms of informal influence. Unlike International Bank for Reconstruction and Development (IBRD) loans, IDA grants are available only to developing countries below a threshold level of per capita income, but some of these eligible countries are members of the Executive Board that has responsibility for overseeing the management of the IDA and ratifying the disbursement of the grants. Previous work has found that members of the Executive Board receive an increased share of IBRD loans, presumably because Executive Directors have improved access to information and to senior staff, which gives them an advantage in pressing their countries' cases (Kaja and Werker 2010). Morrison finds that this was the case in the IDA as well in the 1980s, but that the effect of being a member of the Executive Board became attenuated and eventually disappeared after the process of awarding IDA grants was conditioned on Staff evaluations of country performance in implementing the goals of previous projects. Morrison concludes that this indicates that formal changes in institutional procedures can blunt informal influence. Delving more deeply into the case, however, Morrison finds that the adoption of the reform in question was itself driven by the informal influence of the leading donors to the IDA. Unlike IBRD financing, IDA grants come from a pool of contributions by the leading aid donors, so the periodic replenishments of the pool provide an opportunity for the donors to exert informal influence over the rules of the game. These rules are formally set by the Executive Board, but members of the Board understand that ignoring the preferences of the donors might affect their participation. In the case at hand, the United States and other key donors explicitly linked their commitments to reforming the formal rules.

\section{Institutional change and adaptation}

Most of the papers address the issue of institutional change. The model of informal governance identifies two driving forces behind institutional features: the distribution of issue-specific resources among states, and the degree of anticipated conflict of interest among them within an issue area. This perspective treats states as the primary actors in institutional design and looks for changes in the distribution of power or the interests of the leading states to explain institutional change. 
Two of the papers challenge this statist perspective. Jeffrey Chwieroth argues that essential features of organizational behavior are driven by an international organization's staff. In his account, an IO's dominant understandings of the world and of its own mission are shaped by the pattern of recruitment into staff positions, and gradually change in response to intellectual currents in which the IO is embedded. So, for example, his paper argues that the IMF staff gradually became populated by economists trained in top departments, and these shifts in the staff led to a changed pattern of interaction with member countries. Along similar lines, his previous book argued that the IMF position towards capital controls gradually evolved to mirror that developing in top economics departments, but with about a 10-year lag that reflected the amount of time needed for new economists to reach policymaking positions (Chwieroth 2010). Kevin Morrison makes a similar argument about the World Bank, finding that entrepreneurship within the staff played a key role in developing the Country Policy and Institutional Assessment (CPIA), which ultimately allowed the staff to reassert control over the distribution of IDA funds on the basis of performance criteria. These papers also attribute a substantial role to state action, however, and the other papers focus on state actors exclusively.

There is a tension in the papers between the hypothesis of farsighted institutional design and retrospective adaptation. The papers by Koremenos and Marcoux-andUrpeleinen emphasize rational expectations in the process of institutional design. In contrast, Morrison finds that the degree of informal influence that developing-country executive directors at the World Bank exerted over IDA loans to their own countries was an unanticipated outcome, and that subsequent reforms were in part intended to rectify this unequal treatment. Similarly, Kleine finds that the rotating presidency of the European Council was adapted to solve the credibility problems posed by the informal norms of the European legislative process. The Vabulus and Snidal paper suggests that these examples are part of a systematic pattern: informality provides adaptive advantages. They argue that formal institutions are more costly to change than informal ones, and therefore provide some insurance against declining power, but that informal organizations can more readily adapt to changing circumstances and prevent the collapse of cooperative arrangements when circumstances change.

An implication of the model of informal governance is that informality is in tension with legitimacy. Informal channels of influence generally serve the interests of powerful countries, which are most able to take advantage of the opportunities they present, and which have to be shown some degree of deference in order to secure their participation. Otherwise, powerful countries tend to find alternative instruments to achieve their goals. Chwieroth finds a similar tension, as informal influence by the staff skews access to IMF resources. Morrison finds that informality can also shift the playing field in favor of developing countries that hold strategic positions in the governance structure, but again, at some cost to legitimacy. Vabulus and Snidal argue that the existence of both formal and informal international organizations side by side helps to resolve some of these tensions. In the case of the chemical weapons regime, they find that a formalized monitoring regime with an inclusive membership, which is focused on promoting transparency and broad consent to standards, exists alongside an informal club of powerful states that is designed to share confidential information and coordinate informal enforcement efforts.

According to the model of informal governance, the tension between informality and legitimacy drives institutional change. From this perspective, institutional forms 
and behaviors arise from the tension between opportunism and legitimacy, or the participation constraints of the powerful and the weak. Authority delegated to international organizations can be seized by powerful countries, so deepening international integration is usually possible only if powerful countries are willing to accept more formalized modes of governance. For example, the European Communities were transformed into the much more legally robust European Union in order to allow sovereignty to be pooled in ways that would be subject to more transparent procedures. Similarly, the strengthening of the global trade regime required something like the legalized dispute resolution procedure of the WTO, so that the machinery could not be seized by any of the disputants. Extensive delegation of executive power in the IMF is tolerable, by contrast, only because there are so few conflicts of interest among the leading states in international finance. As the distribution of power and interests shifts, however, there may be increasing calls for reining in the informality in the IMF's governance structure.

\section{Conclusions}

International organizations have become central features of the international landscape and key actors in international affairs. They command more resources, preside over a larger body of international law, and penetrate more deeply into the details of domestic politics than ever before. Their increased substantive weight has drawn a corresponding amount of scholarly attention, so that there has been an explosion of empirical research on international organizations in recent years. In the process, studies of a wide range of institutions designed for diverse purposes have uncovered a common pattern: the behavior of international organizations is generally poorly explained by their formal, legal attributes. In fact, international organizations depart systematically from their legal norms, and are widely understood to do so. Understanding the informal governance of international organizations is necessary in order to understand how these organizations actually function.

The papers collected here make a modest contribution to this project. They were collected through an open call for papers, so they are theoretically and empirically diverse. They represent a relatively broad cross-section of quality empirical work on international organizations. Nevertheless, they underscore a certain consensus that is emerging among scholars studying a wide range of institutions that the informal elements of organizational governance are critical to understanding organizational behavior. By informal governance we mean a systematic influence of unwritten rules, shared expectations or norms within international organizations that substantially modify or substitute for formal treaty provisions.

The purpose of the special issue was to open up questions rather than to resolve them prematurely, and the result is that some of the papers draw heavily on the model of informal governance sketched here, while others contest important parts of it. Most of the papers embrace the key insight of the model, which is that informality is a concession made by the weak to the strong. Informal governance in this view allows countries with attractive outside options to commit themselves to institutions, because they can substantially control the outcomes of greatest importance to themselves. In return, powerful countries shed most of the visible levers of power and allow weaker 
states to take over the lion's share of formal decision rights. This compact is legitimate only so long as it provides positive expected returns to all of the participants; and this participation constraint prevents the exercise of informal governance from becoming routine. Most of the papers find this characterization of informal governance apt in their particular contexts. Three of the papers insist on the relevance of functional explanations, however. The Koremenos and Vabulus-and-Snidal papers combine explanations based on power with explanations based on transaction costs and contracting problems, arguing that the two perspectives complement each other and that combining them helps to resolve anomalies. Kleine finds that power resources are not particularly relevant to the cases of legislative politics in the European Union that she studies.

The papers offer broad conclusions about organizational behavior, organizational design, and interactions among international organizations.

The papers that focus on organizational behavior find that informal governance is pervasive, often contradicts the patterns that would be predicted by formal governance arrangements, and corresponds to the quality of countries' outside options. However, they also find that international organizations are complex entities, and that some of this complexity is not captured in the stylized model of informal governance sketched here. In particular, Chwieroth argues that the effort to understand IMF behavior should not stop with the strategic interactions of member states, but should reach deep into the principal-agent chains within the organization and understand the beliefs of the agents who are setting the agenda. Morrison finds that patterns of informal influence are complex and may oppose each other. The informal influence of developing-country members of the World Bank's Executive Board allows them to manipulate the terms of loans to their own countries, which was an unintended consequence of an institutional design that favors insiders. The structural power of the IDA donors could be used to change the procedures for allocating IDA grants, however, in ways that ultimately stripped the Executive Directors of effective control.

The papers on organizational design uncovered a series of anomalies. In some cases, formal enforcement rules were omitted from treaties because the existence of informal enforcement rendered them unnecessary. In others, the inclusion of such rules in treaties was only possible because informal influence assured that they could not be used. In each case, the policy implication of the formal design was the opposite of the legal implication: enforcement occurred where it was not provided, and failed to occur where it was provided. In many other cases, of course, formal enforcement works exactly as it is intended to operate. The inescapable conclusion, however, is that informal governance can substantially modify the effect of legal provisions, and is itself an essential element of institutional design.

International institutions interact with each other in complex ways, and understanding these interactions is an important focus for future research. Formal and informal international organizations can function as complements, rather than only as substitutes. Informal organizations can be critical parts of the governance mechanisms of formal organizations, as in the case of the G-7 and G-20, which function as parts of the informal mechanism of controlling the IMF and the World Bank. Informal groupings of states play key roles in the governance of the WTO. Informal organizations can be nested in formal institutions, often UN organs, which provide the hardware that allows them to function effectively, including secretariats. For example, 
the UN provided the secretariat for the GATT until the creation of the WTO in 1995, and the BIS continues to provide the secretariat for the Basel Committee. Treaties can be nested implicitly in other treaty arrangements or informal norms, so that missing formal enforcement procedures can be supplied elsewhere. The existence of the UN Security Council implicitly influences the terms of a wide range of treaties.

International organizations play a key role in contemporary international relations, and informal governance is the key to understanding their behavior and design. The papers that follow provide a cross-section of current empirical studies and point to a number of productive avenues for future research.

\section{References}

Abbott, K. W., \& Snidal, D. (2000). Hard and soft law in international governance. International Organization, 54(3), 421-456.

Bagwell, K., \& Staiger, R. W. (2002). The economics of the world trading system. Cambridge: MIT Press.

Busch, M., \& Reinhardt, E. (2003). Developing countries and the GATT/WTO dispute settlement. Journal of World Trade, 37(4), 719-735.

Büthe, T., \& Milner, H. V. (2008). The politics of foreign direct investment into developing countries: increasing FDI through international trade agreements? American Journal of Political Science, 52(4), $741-762$.

Chwieroth, J. (2010). The IMF and the rise of financial liberalization. Princeton: Princeton University Press.

Coase, R. (1960). The problem of social cost. Journal of Law and Economics, 3, 1-44.

Copelovitch, M. S. (2010). The International Monetary Fund in the global economy: Banks, bonds and bailouts. Cambridge: Cambridge University Press.

Davis, C. L. (2003). Food fights over free trade: How international institutions promote agricultural trade liberalization. Princeton: Princeton University Press.

Davis, C. L. (2004). International institutions and issue linkage: building support for agricultural trade liberalization. American Political Science Review, 98(1), 153-169.

Davis, C. L. (2012). Why adjudicate? enforcing trade rules in the WTO. NJ: Princeton University Press.

Dreher, A., \& Jensen, N. M. (2007). "Independent actor of agent? an empirical analysis of the impact of US interests on IMF conditions." Journal of Law and Economics, 50(1), 105-124.

Dreher, A., \& Vaubel, R. (2004). The causes and consequences of IMF conditionality. Emerging Markets Finance and Trade, 40(3), 26-54.

Dreher, A., Sturm, J.-E., \& Vreeland, J. R. (2009). Development aid and international politics: does membership on the UN Security Council influence World Bank decisions? Journal of Development Economics, 88(1), 1-18.

Fang, S., \& Stone, R. W. (2012). International organizations as policy advisors. International Organization, $66(4), 537-571$.

Fleck, R. K., \& Kilby, C. (2006). World Bank independence: a model and statistical analysis of U.S. influence. Review of Development Economics, 10(2), 224-240.

Goldstein, J., Kahler, M., Keohane, R. O., \& Slaughter A.-M., (eds.) (2000). Legalization and World Politics: A Special Issue of International Organization. International Organization, 54(3) (Summer).

Gould, E. R. (2006). Money talks: The International Monetary Fund, conditionality, and supplementary financiers. Stanford: Stanford University Press.

Hawkins, D. G., Lake, D. A., Nielson, D. L., \& Tierney, M. J. (Eds.). (2006). Delegation and agency in international organizations. New York: Cambridge University Press.

Kaja, A., \& Werker, E. (2010). Corporate governance at the World Bank and the dilemma of global governance. World Bank Economic Review, 24(2), 171-198.

Keohane, R. O. (1984). After hegemony: Cooperation and discord in the world political economy. Princeton: Princeton Univ. Press.

Keohane, R., \& Nye, J. (1977). Power and interdependence: World politics in transition. Boston: Little, Brown and Co. 
Kleine, M. (2013). Making cooperation work. Informal governance in the EU and beyond. Ithaca: Cornell University Press.

König, T., Luetgert, B., \& Dannwolf, T. (2006). Quantifying European Legislative Research: using CELEX and PreLex in EU legislative studies. European Union Politics, 7(4), 553-574.

Koremenos, B., Lipson, C., \& Snidal, D. (2001). The rational design of international institutions. International Organization, 55(4), 761-800.

Mansfield, E. D., \& Milner, H. V. (2012). Votes, vetoes, and the political economy of international trade agreements. Princeton: Princeton University Press.

Mansfield, E. D., \& Reinhardt, E. (2003). Multilateral determinants of regionalism: the effects of GATT/ WTO on the Formation of Preferential Trading Arrangements. International Organization, 57(4), 829862.

Oatley, T., \& Yackee, J. (2004). American interests and IMF lending. International Politics, 41, 415-429.

Pop-Eleches, G. (2009). From economic crisis to reform: IMF programs in Latin America and Eastern Europe. Princeton: Princeton University Press.

Reinhardt, E. R. (2001). Adjudication without enforcement in GATT disputes. Journal of Conflict Resolution, 45, 174-195.

Schneider, C. J. (2009). Conflict, negotiation and European Union enlargement. Cambridge: Cambridge University Press.

Steinberg, R. (2002). In the shadow of law or power? consensus-based bargaining and outcomes in the GATT/WTO. International Organization, 56(2), 339-374.

Steinwand, M., \& Stone, R. W. (2008). The international monetary fund: a review of the recent evidence. The Review of International Organizations, 3(2), 123-149.

Stone, R. W. (2002). Lending credibility: The international monetary fund and the post-communist transition. Princeton: Princeton University Press.

Stone, R. W. (2004). The political economy of IMF lending in Africa. American Political Science Review, $98,577-591$.

Stone, R. W. (2008). The scope of IMF conditionality. International Organization, 62, 589-620.

Stone, R. W. (2011). Controlling institutions: International organizations and the global economy. Cambridge: Cambridge University Press.

Thacker, S. C. (1999). The high politics of IMF lending. World Politics, 52, 38-75.

Thompson, R., Stokman, F. N., Achen, C. H., \& König, T. (2006). The European Union decides. Cambridge: Cambridge University Press.

Vreeland, J. R. (2003). The IMF and economic development. Cambridge: Cambridge University Press.

Williamson, O. E. (1975). Markets and hierarchies: Analysis and antitrust implications. A study in the economics of internal organization. New York: The Free Press.

Williamson, O. (1985). The economic institutions of capitalism. New York: Macmillan. 